\title{
Jøden og
orientaleren \\ Jøden og
orientaleren
}

Et essay

Af Morten Thing

Hvordan blev jøden semit og hvordan blev jodehaderen antisemit? Orientaliseringen af Europas jøder bang sammen med dybtgaiende kul- turelle andringer. 
des: “orienterer, jeg, mig, egentlig: retter mig mod Østen; hvilket man til Søes, før Magnetnaalens Opfindelse, maatte giøre, for ved Solens Op- og Nedgang at adskille hvad Kant man var paa". ${ }^{2}$ Før kompasset gjorde nord til et passende sted at starte orienteringen, så en sømand mod oriens, solopgangshjørnet, og vidste så allerede mere om, hvor han var. Videnskabernes Selskabs Dansk Ordbog fra 1826 anfører meget sigende et dansk paralleludtryk til 'orientere sig': at 'østne sig'. Ludvig Meyers fremmedordbog ${ }^{3}$ fra 1837 skriver under 'orientere sig': “eg. søge Solens Opgang, rette sig mod Østen, for at finde de øvrige Verdensegne; fig. gjøre sig bekjendt med sin Stilling og sine Omgivelser, gjøre sig nøie bekjendt med noget, gjenfinde sig, finde til Rette." At denne etymologi stadig var fuldt bevidst senere i århundredet ses af, at Grundtvig da han i 1867 genudgav sin Haandbog $i$ Verdenshistorien fra 1833 ændrede ordet 'orientere' til 'solrette' i overensstemmelse med sin sprogrensende, puristiske indstilling til fremmedordene. ${ }^{4}$

For Rushdie indgår denne etymologiske betragtning imidlertid i forbindelse med ordet at 'desorientere', altså at miste Østen, men også overblikket, retningen, orienteringen. Det er hans hovedperson, den moderne og indiske Orfeus, Ormus Cama, som, efter han er kommet til Vesten, mister Østen. Rushdie bruger udtrykket til at indfange det som sker for østerlændingen, når han eller hun blander sig og sin kultur - og det gør man altid hos Rushdie. Desorientering er et forsøg på at indfange noget centralt ved hele den kulturelle proces, som ifølge Rushdie altid er blandinger og aldrig renhed. Desorientering er både udtryk for noget uomgxngeligt, men også udtryk for en skrøbelighed i den personlige dimension. Havde han kunnet dansk, var Rushdie sikkert faldet for slangudtrykket 'desorientalsk'.

Ormus er som sagt med et lidt ældre ord en 'østerlænding'. Han kommer fra Østerland eller Morgenland, han er en 'orientaler'. Denne lidt uspecifikke omgang med

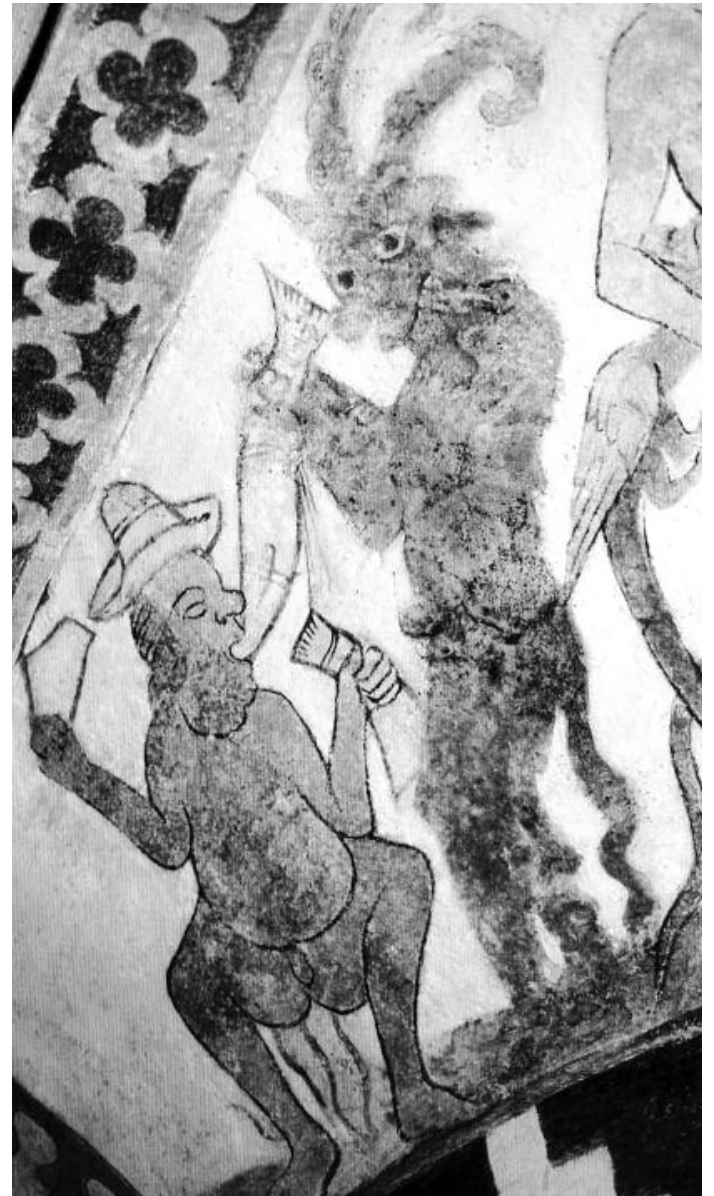

Selvom der ikke fandtes joder i Danmark for omkring 1500, optreder de i mange kalkmalerier. Jeg viser en rakke $i$ denne artikel, alle gengivet efter Ulla Haastrups retningsgivende artikel i Dansk jodisk kunst (1999). I dette billede fra Birkerod Kirke, ca. 1325, er der tale om en dommedagsfremstilling, hoor en fed nogen mand fär holdt flydende guld $i$ halsen. At manden er en jode fremgair ikke mindst af, at han er de eneste af 'dodssynderne', som borer hat, det mest almindelige jodetegn $i$ kalkmaleriernes billedkode. Men han har tillige skag, er fremstillet i profil og har en stor nase, alle trak fra billedkoden: jode.

geografien i ældre tid hang naturligvis sammen med et manglende detailkendskab til de mange forskellige folk, som beboede området fra Bosperus til Stillehavet. Går vi 
endnu længere tilbage, f.eks. til Mandevilles Rejse, som formentlig er oversat til dansk i 1444, omtales de fremmede Mandeville møder som 'saracener', som blot skal forstås som muslimer. Han fortæller om "machomets bogh som tee kallæ alchoran" [Muhammeds bog som de kalder Koranen] og skelner saracenerne fra "cristnæ eller iødher". 5

For den danske oversætter var 'iødhernæ' ikke noget nyt bekendtskab, sådan som saracenerne sikkert var det. De optrådte jo i Biblen. Ordet var kommet til os enten i dets latinske form 'iudaeus' eller dets græske 'iūdaîos' med rod i det hebraiske 'jehūdā'. Fra bibeloversættelser var ordet gledet ind i de germanske sprog. Dansk har formentlig lånt ordet fra middelnedertysk 'jode', mens svensk og islandsk lånte sideformen 'jude'. ${ }^{6}$ Forskellen mellem oversætteren og f.eks. en bruger af ordet 'jode' i den sydlige del af Tyskland kunne være, om de kun kendte jøderne fra Biblen eller havde mødt én i virkeligheden. Chancen var betydelig større i Sydtyskland end i Danmark i midten af 1400-tallet.

Hvor Ormus Cama, den moderne Orfeus, bliver til noget andet ved at blive desorienteret, så var saracenen eller jøden 'den anden’ for oversætteren af Mandevilles forbløffende udlandsfærd. 'Den anden' er en kategori som nødvendigvis indgår i al kommunikation og i al identitetsdannelse. Men 'den anden' forstået som 'den fremmede anden' er tillige målestok på det som 'jeg' har fælles med andre, men ikke med 'den fremmede anden'. Den 'fremmede anden' indgår dermed som grundstørrelse i dannelsen af kollektiv bevidsthed. For den (formentlige) munk som oversatte Mandeville til dansk var den kollektive bevidsthed af religiøs art: kristne, jøder, saracener. I en sådan religiøs, kollektiv bevidsthed er det afgørende hvad du tror. Du er så at sige, hvad du tror på. Ved at skifte tro blev du en anden.

Kristendommens forhold til jøderne undergik mange faser, som ikke her skal opregnes. Blot skal det påpeges, at jøderne oprindelig (dvs. fra og med Augustin) havde en anden status end andre vantro. Kristendommen var sig bevidst at være en fortsætterreligion til jødedommen. Ved at jøderne eksisterede, vidnede de for kristenheden om, at hele den lange vej fra Moses til Jesus var indstiftet af Gud; jødernes fejl var bare den, at de ikke ville anerkende at Jesus var Messias. I perioder ændredes dette til valget mellem døden eller dåben. ${ }^{7}$ Men i dette valg lå altså en karakteristik af religionen som identitet, som oversvømmede alle andre, lokale og individuelle identiteter. En jøde var i dette valg altså i første række en Guds skabning og først derefter jøde.

At jøden også var en 'østerlænding' eller en 'orientaler' i samme forstand som negeren var neger, lå uden for eller i yderste randzone af denne opfattelse. Negre var kendt i middelalderen, og det var kendt at det var arveligt med den mørke hudfarve. Forestillingerne om, hvor deres hudfarve kom fra var mange, bl.a. at de boede txt på solen og var blevet brankede. På oldislandsk hed en neger 'bláma r', blåmand, og ordet brugtes på dansk i konkurrence med 'mor' og 'morian' frem til 1800-tallet. Voltaire mente at negrene var en art mellem aber og hvide mennesker. Men interessant nok var siden senmiddelalderen én af de tre vise mænd, Sankt Mauritius, afbilledet som sort. De sorte kunne rummes indenfor den religiøse identitet.

Det er først med dannelsen af den moderne og individualiserede identitet at dette afgørende ændres. I denne proces indgår paradoksalt nok verdens skrumpeproces gennem opdagelserne. Forklaringen på at skrumpeprocessen førte til en 'fremmedgørelse' af de gule, sorte, røde og brune er at verden samtidig blev koloniseret. Valget var ikke længere dåben eller døden, det var arbejde eller døden. Det at resten af verden blev til objekt for Europa, gjorde det - i perioden fra humanismens gennembrud til menneskerettighedernes tilblivelse - stadig mere oplagt for hvide mennesker at hievarkisere mennesker. Ikke en social hierarki- 
sering som den man kendte fra det feudale Europa; ikke klasser, men menneskegrupper-som-klasser, folk-som-klasser, racer-somklasser. Denne proces hen imod hierarki som menneskelig skæbne afsvækkes ikke i perioden fra menneskerettighedernes proklamation til demokratiets sejr som politisk system. Det sker nemlig samtidig med at denne verden af andet-hed gøres til et reservoir af arbejdskraft og naturressourcer. Og denne objektstatus var inkompatibel med ligeret som menneske.

Som sædvanlig fik de ideologiske behov hjælp fra videnskaben, i dette tilfælde bl.a. fra biologien, som fra 1850erne udviklede sig med stormskridt via Mendels arvelighedsteori (1850), med celleteorien (1855) og med Darwins evolutionsteori fra 1859. Biologien fusionerede med kulturhistorien, som siden slutningen af 1700-tallet havde mangfoldiggjort Kultur til kulturer. Kulturen blev i 1870erne med Lewis Henry Morgan $^{8}$ og andre kulturhistorikere evolutioneret i tre hovedfaser: vildskab, barbari og civilisation. Hermed blev det sandsynliggjort, at menneskeheden og dens forskellige racer havde gennemløbet det samme opadstigende historiske mønster, en tanke som gik tilbage til Hegels historiefilosofi. Denne relativering blev i stigende grad imødegået af en biologisme, som så hierarkiseringen af racerne som biologisk givne, så det altså ikke stod til at ændre, at de hvide var de mest civiliserede og de sorte de mest vilde og med de gule, de brune og de røde indimellem.

Biologiseringen af kulturelle forskelle blev også boostet af nationalismens udvikling. Den nationale ideologi som tankeform blev til i løbet af 1800-tallets første del og tog især fart efter 1848. Nationalismen er, som Benedict Anderson har foreslået, et 'forestillet fællesskab'. 9 Det er et fællesskab, som hviler på en række fællestræk, som udgrænser forstyrrende, heterogene grupper. Det danske nationale fællesskab rummede således ikke islændinge, færinger og grønlændere. De var simpelthen ikke danske. Og Grundtvig gik så langt som til at skrive, at Goldschmidt som jøde, og derfor som gxst hos 'os', ikke havde nogen ret til at tale med om danskhed. 10

Nationalismen var bygget på et forestillet fællesskab som monolitisk var bygget op på enheden: landområde, historie, sprog og folk. Det medførte blodige og groteske tilpasninger til forestillingen: den voldsomme frankoficering af de ikke-fransktalende i Frankrig eller russoficeringen af de ikkerussisktalende i Rusland, folkemordet på armenerne i Tyrkiet eller den tvangsmæssige udskillelse af grækere og tyrkere fra henholdsvis Tyrkiet og Grækenland.

Jøderne og sigøjnerne kom i klemme i denne historiens slipstrøm: de havde deres egen historie, de udgjorde et folk og talte egne sprog (jiddish, judezmo, romani), men de havde ikke noget land og var set med den nye nationalismes øjne gester. De to grupper adskiller sig fra hinanden i henseende til skrift: hvor jødernes historie som vi kender den fremfor alt er knyttet til netop skriften, er sigøjnerne knyttet til mundtligheden. Hvor jødernes oprindelse er beskrevet i Skriften, fortaber sigøjnernes oprindelse sig i myter som er blevet fortalt og genfortalt. Romani er et indo-iransk sprog, og det anses for sandsynligt at sigøjnernes forfædre oprindelig har været bosat i det indiske område. I denne genealogiske forstand kan altså både jøder og sigøjnere anskues som østerlændinge, som orientalere.

Men hvad vil en sådan genealogisk betragtning egentlig? Den trækker en linje fra individ til individ bagud, men trækker den også hermed en kontinuitetens linje gennem folkets historie? Er der med andre ord en kulturel kontinuitet langs en sådan genealogisk linje? Nationalhistoriens udsagn er at der findes en sådan kontinuitet. De mange Danmarks-historier kan opfattes netop som forsøg på at homogenisere linjen bagud. Og selvom man kunne indvende, at et betydeligt antal heterogene elementer udskilles, kan en sådan konstruktion ikke afvises som værende helt uden referent $\mathrm{i}$ virkeligheden. 


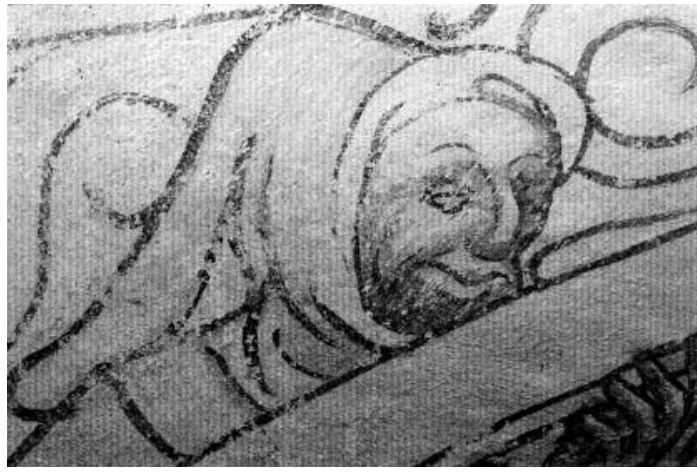

En jode fra Brönnestad Kirke, Skaine, ca. 1425. Hans store buede nase og hatten viser ham som jode.

Biologismen gik imidlertid et skridt videre: den ønskede at udvide genealogien til en linje fra ægcelle til ægcelle og fra spermatozo til spermatozo. Den ønskede at 'folk' betød et fællesskab af anderledes objektiv, nemlig genetisk, art: en dansker var en dansker ved at nedstamme fra danskere. Sagt i moderne genom-sprog: en dansker havde gener fælles med sine forfædre helt tilbage i myternes urtåger. Ikke nok hermed: til forskel fra tyskerne, englænderne osv. udgjorde hvert folk en sådan fælles genpulje. Og især: der var nogen som var 'de andre': jøderne og sigøjnerne var helt, helt anderledes, de var jo orientalere. Dette nye udkast til en biologisk begrundet kulturhistorie var, hvad der stod på dagsordenen i de sidste årtier af forrige århundrede og frem til 6 millioner jøder og 750.000 sigøjnere måtte lide den industrielle død som en konsekvens af dette kultur- og menneskesyn.

\section{JØDEN SOM ORIENTALER}

Nationalismen og biologismen indgik tillige et ideologisk ægteskab med den fremvoksende sprogvidenskab. Den sammenlignende sprogvidenskab fra William Jones til Rasmus Rask udviklede (fra 1786 til 1822) den tese, at europæiske sprog som græsk, latin og de germanske sprog havde så mange frllestræk med sanskrit, at det kunne antages, at de nedstammede fra samme grundsprog. Dette grundsprog, antog man, var blevet talt af 'ariere', et folk man placerede langt tilbage i fortiden og geografisk et sted mellem Indien og Iran. Man talte om indo-europæiske eller om indo-ariske sprog.

Den sproglige genealogi blev hurtigt overført til de andre nævnte genealogier. Joseph-Arthur de Gobineaus værk Essai sur l'inégalité des Races Humaines (1853-55) var det første til at koble disse træk. Racerne var således de biologiske bærere af den sproglige genealogi. Men racerne var ikke lige, tværtimod var de ordnet $i$ et system af uligheder. Fra Gobineau, som egentlig blot var tilhænger af l'ancien regime, udvikledes $\mathrm{i}$ sidste halvdel af 1800-tallet en ny kulturel topologi: tidligere havde man regnet jøderne til 'de hvide', nu tilhørte de pludselig en anden race: den semitiske. Den semitiske race omfattede de folk, som talte semitiske sprog, dvs. araberne - og jøderne, fordi deres sprog jo 'egentlig' var hebraisk. Argumentationen var bygget op som en catch 22: man tilhørte en race som talte et sprog tilhørende en bestemt sprogxt, og gjorde man ikke det, gjorde man det alligevel, fordi ens forfædre havde gjort det! Fra Gobineau til tyskeren Houston Stewart Chamberlains Die Grundlagen des neunzehnten Jahrhunderts (1899) udvikles denne tanke, som imidlertid allerede ligger hos Grundtvig, som anså Goldschmidts 'egentlige' sprog for at være "ebraisk", som han sagde."1

Determinismen var en overgribende videnskabelig tankeform. Forestillingen om det uundgåelige og entydige gjorde disse forestillinger mulige og udbredte dem. Men det interessante er, at modargumenterne er lige så gamle. Den berømte filolog Max Müller sagde allerede i 1871 at snakken om en 'arisk race' var lige så vanvittig som en langskallet syntaks. Og i den antropologiske litteratur var der mange tilbagevisninger af ideen om en semitisk race. ${ }^{12}$ Faktisk er tilbagevisningslitteraturen en fast genre helt frem til efter anden verdenskrig. Skal man kort opsummere de mange un- 
dersøgelser af 'jøderne som race', så udgør jøderne en række meget forskellige grupper i henseende til fysisk antropologi (kraniemål, blodtype, øjenfarve, hårfarve, hudfarve, hårtværsnit etc.): ashkenaziske, sefardiske, orientalske, jemenitiske, indiske, kinesiske. De ligner mere de folk, de har boet blandt end hinanden. Den danske arvebio$\log$ J.V. Spärck opsummerede i 1954 forskningen således: "Det eventuelle jødiske særpræg må da - forsåvidt det overhovedet eksisterer - formodentlig forst og fremmest tilskrives tradition og opdragelse snarere end arveanlæg. Ophører derfor et specifikt jødisk miljø at eksistere, vil også det eventuelle jødiske præg forsvinde". ${ }^{13}$

Konstruktionen af den semitiske race flyttede pludselig jøden mange tusinde kilometer i den mentale geografi. Fra at være en del af 'de hvide' var jøderne gjort til ét med araberne og andre folk i Mellemøsten. Selvom jøderne ikke ændrede udseende eller væremåde, blev de mentalt ghettoiseret efter at være blevet fysisk befriet for pligten til at bo i ghettoer. Jeg skriver med vilje 'konstrueret'. Det gør jeg uden at låne metodiske indsigter fra socialkonstruktivismen eller diskursanalysen, som jeg forholder mig kritisk til. Men præcis tilblivelsen af jøden som semit fremhæver dén rigtige indsigt $\mathrm{i}$ begge skoler, at sociale relationer skal udtrykkes sprogligt for at kunne gøres til en del af det socialt-kulturelle kampfelt. Dét er indholdet i metaforen 'konstrueret'.

Med jøden-som-semit blev jøden også orientaler, flyttet til den mellemste Orient, ikke fysisk, men mentalt. Semit og orientalsk blev de samlende begreber som skulle forklare alt dét særlige ved jøderne, som gjorde dem til 'de fremmede andre'. Det kunne naturligvis kun ske gennem en voldsom overbelastning af begreberne. Hvis der var tale om en teori i grengs videnskabelig forstand. Men det er der ikke, hvorfor 'begreb' er misvisende. Som Sartre gør opmærksom på i Reflexions sur la question juive er antisemitismens form prelogisk: "Hvis således antisemiten er uigennemtrængelig for fornuft og erfaring, som enhver kan se, er det ikke fordi hans overbevisning er stærk; langt snarere er hans overbevisning stærk fordi han har valgt fra begyndelsen at være uigennemtrængelig." 14

Med jøden-som-semit opstod også ordet antisemitisme. Det blev brugt første gang af den tyske forfatter Wilhelm Marr i 187915 til at adskille hans holdning fra det religiøse jødehad. På tysk skelnes nogen gange mellem 'Antisemitismus' og 'Rassenantisemitismus' for at tilgodese dette nye paradigme i jødehad. Helt i tråd med antisemitismens prælogiske karakter kan man indvende, at termen er mærkværdig, fordi der ikke eksisterer nogen semitisme man kan være imod. 16

\section{OtTo Weininger}

Den østrigske filosof Otto Weininger var kun 23 år, da han i 1903 udgav bogen Geschlecht und Charakter. Bogen har øvet en stor og forbløffende indflydelse på mange af tidens kunstnere og filosoffer, som ikke blev mindre af, at Weininger begik et spektakulært selvmord samme år bogen udkom ved at skyde sig i hjertet i det hus, hvor Beethoven døde. Kafka, Wittgenstein, James Joyce, Karl Kraus, Strindberg og Isaac Bashevis Singer var stærkt optaget af dette antifeminismens og antisemitismens hovedværk.

"Denne bog sætter sig til Opgave at belyse Forholdet mellem Kjønnene paa en ny og afgjørende Maade. [...] Den dvæler ikke ved dette eller hint Idyl, men trænger frem indtil et sidste Maal; den hober ikke Iagttagelse paa Iagttagelse, men bringer Kjønnenes aandelige Differenser i System; den handler ikke om Kvinderne men om Kvinden." (s. I) ${ }^{17}$ Sådan lyder det i den danske oversættelse fra 1905. Weininger skrev direkte: "[...] Fremstillingen er antifeministisk." (s. III), selvom han præciserede mange gange, at han ikke skrev om levende mennesker, men om idéer: "Der gives utallige trinvise Overgange mellem Mand og Kvinde, sexuelle Mellemformer. [...] saaledes 
kunne vi som sexuelle Typer opstille en ideal Mand $M$ og en ideal Kvinde $K$, som $i$ Virkeligheden ikke findes. Disse Typer ikke blot konstrueres, de maa konstrueres. Typen, den platoniske Idee, er ikke blot Kunstens Objekt, men ogsaa Videnskabens." (s. 24)

Weiningers bog på over 600 sider handler især om køn. Han placerer de to køn i hver sin ende af en bipolær skala. Mellem disse to yderpunkter finder vi såvel biseksualiteten som homoseksualiteten. De befinder sig altså på den samme skala, hvor alle andre muligheder findes, som må betragtes som blandinger af de to polariteter. Biseksualitet og homoseksualitet ses altså ikke som fejludviklinger, men som tilfælde på lige fod med alle andre. Weininger kendte til og refererer til Freud og integrerer hans forestilling om, at alle ikke blot er biseksuelle i en eller anden udstrækning, men også at alle er homoseksuelle i en eller anden udstrækning.

Hermed er måske introduceret en side af Weiningers bog, som fascinerede så voldsomt i samtiden: bogen er i sin form bygget op som en principiel og logisk undersøgelse, som også fører til overraskende og i samtiden provokerende resultater. Men ser vi på hans langstrakte forsøg på at isolere de to polariteter $M$ og $K$ er resultatet ikke overraskende: " $K$ gaar fuldstendig op $i$ Kjonslivet, $i$ Parringsspheren d.v.s. $i$ Forholdet til Manden og til Barnet, hendes Existens udfyldes fuldkomment af disse Ting, medens $\boldsymbol{M}$ ikke blot er sexuel. [...] Medens altså $K$ er ganske udfyldt af Kjønsligheden, kjender $\boldsymbol{M}$ endnu et Dusin andre Ting: Kamp og Leg, Selskabelighed og Svirelag, Diskussion og Videnskab, Forretning og Politik, Religion og Kunst.” (s. 163) Den abstrakte kvinde defineres altså udelukkende som seksualitet, mens manden er noget mere. Det viser sig, at kvinden ikke kan adskille tænken og følen, ja, at hun lever ubevidst. Når det kommer til stykket har kvinden nemlig ingen ånd og "Genialitet aabenbarer sig allevede her som en Art hoiere Mandlighed; og derfor kan K ikke vare genial." (s. 202). Videre i undersøgelsen vi- ser det sig: "Den absolute Kvinde hav intet jeg." (s. 334). Og derfor et par sider længere fremme: "Genialitet er identisk med Dybde, og man forsøge kun at forbinde "dyb" og "Kvinde" med hinanden som Attribut og Substantiv, enhver hører strax Selvmodsigelsen. En kvindelig Genius er folgelig en contradictio in adjecto." (s. 337) Sagt på en anden måde: "Forholdet mellem Mand og Kvinde er intet Andet end det imellem Subjekt og Objekt. Kvinden søger sin Fuldendelse som Objekt [...].” (s. 543) $\mathrm{Og}$ selvom Weininger forsøger at fastholde det principielle i sin undersøgelse og bruge $M \operatorname{og} K$ om sine analyseobjekter, så hedder det konkluderende: "Den dybest staaende Mand staar altsaa endnu uendelig boit over den hoiest staaende Kvinde." (s. 476)

Når moderne kvinder på Weiningers tid kæmper for emancipation, er det et oplagt emne for ham at undersøge, og undersøgelsen "[...] munder ud deri, at Emancipationstrangen og Emancipationsevnen hos en Kvinde er begrundet $i$ den Andel, som hun har $i$ M." (s. 121) Det er altså mandliggørelsen af kvinden, der afstedkommer emancipationen, som Weininger anser for usund og ukvindelig. I forlængelse heraf ser han hele sin samtids kunst, bl.a. hos Gustav Klimt (secessionismen) som et udtryk for en forkert eller manglende polarisering af kønnet. Han henviser til, at "[...] den Kjendsgerning, at der til visse Tider fødes flere mandlige Kvinder end ellers, vilde som Pendant paa den modsatte Side forlange, at der paa samme Tid ogsaa bragtes flere kvindelige Mænd til Verden. Den hele secessionistiske Smag, der giver den store slanke Kvinde med flade Bryster og smalle Hofter Skjønhedsprisen, kan maaske føres tilbage dertil. Den uhyre Forøgelse af Lapsevæsnet saavel som Homosexualiteten i det sidste Aar kan kun have sin Grund i den nuværende Æras større Kvindelighed.” (s. 136)

Selvom Kjon og Charakter især er en antifeministisk traktat, har den et sidespor som tages op i kapitel XIII, nemlig jøderne. Jøderne analyseres som menneskehedens 
kvinder. Det er lidt interessant, da Weininger selv var (en døbt) jøde.

Weininger ser på selve racespørgsmålet med nogen tvetydighed. Indledningsvis kan han skrive " $[\ldots]$ at denne Undersøgelse forst og fremmest har angaaet den ariske Mand og Kvinde." (s. 562) Ligeledes antager han den fysiske antropologis argumentationsform: "Jødedommen synes anthropologisk at have et vist Slægtskab med begge de omtalte Racerne, Negrene og Mongolerne. Om negeren minder det krusede Haar, og

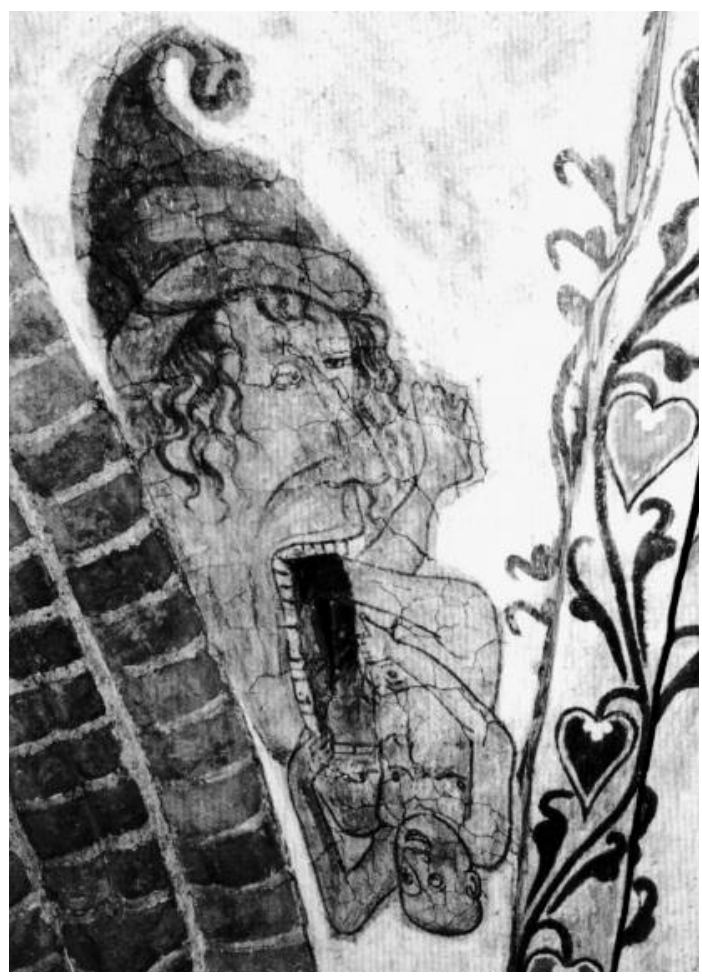

En vrongemaske, St. Marie Kirke, Helsingor, ca. 1490. Masken forestiller en jode (hat, stor nese, orekroller) som med enorm mund fortorer et lille barn.

paa det mongolske Blod tyder den chinesisk eller malaisk formede Hjerneskal, som man saa ofte træffer hos Jøderne, og til hvilken der regelmæssig svarer en gullig Hudfarve." (s. 563). Ikke desto mindre mener han også, at det at være jøde er noget indre, en personlig fejludvikling, som kan overvindes af den enkelte, som hermed altså må tænkes at kunne skifte race fra semit til arier.

Jødernes rolle ser Weininger således: "Og det er foreløbig sagt, at maaske er Jødedommens verdenshistoriske Betydning og store Fortjeneste ingen anden end den, bestandig at bringe Arieren til Bevidsthed om sit eget Selv." (s. 568) Derved adskiller jøden sig fra kvinden, som modtager bevidsthed fra manden. Analysen af jøden ligner ellers analysen af kvinden. Det hedder således: "Men det er denne kantiske Fornuft, Aanden, der synes at mangle saa vel hos Jøden som hos Kvinden"(s. 571), “[...] at han ligesom Kvinden mangler Personlighed [...]" (s. 572), "Der gives ingen jødisk Adel [...]" (samme) og "[...] thi den xgte Jøde har ligesom Kvinden intet Jeg og derfor heller ingen Egenværd." (samme)

Weiningers kulturkritik er også en modernitetskritik, og han ser derfor ikke overraskende jøderne som repræsentanter netop for det moderne: "Modernitetens Aand er jødisk [...]. Vor Tid, er ikke blot er den mest jødiske, men ogsaa den kvindagtigste af alle Tider: den Tid, der bruger Kunsten som en Svededug for sine Stemninger og afleder den kunstneriske Trang af Dyrenes Lege [...]." (s. 617) Set med Weiningers øjne er der også det karakteristiske ved jøder og politik, at "Socialismen (Owen, Carlyle, Ruskin, Fichte) er arisk, Kommunismen jødisk (Marx)." (s. 570) Man kan se et tidstypisk angstkompleks hos Weininger dannet af 'det andet' (kvinden, jøden) og 'det moderne'. Freud skriver en passant om Weininger: "Weininger var som neurotiker helt besat af infantile komplekser; relationen til kastraktionskomplekset er det, der her er fælles for jøden og kvinden."18

"Jødedommen er den Afgrund, som Christendommen er opreist over, og derfor er Jøden Arierens sterkeste Frygt og dybeste Afsky." (s. 615) Sådan beskriver Weininger forholdet mellem jødedom og kristendom. Ikke overraskende bliver kristendommen den måde, hvorpå jøden kan undslippe sin 
jødiskhed. "Men hertil udkrævedes først og fremmest, at Joderne forstaa sig selv, at de lave at kjende sig selv og bekjempe sig selv, at de inderlig vil beseive Jødedommen $i$ sig selv." (s. 581) Mod slutningen af sin analyse har Weininger forladt det biologiske raceparadigme og har bevæget sig tilbage til muligheden for at jøden med Augustins udtryk igen bliver seende og modtager dåben. Selve bogens projekt, den principielle undersøgelse af kønnet, ender i kravet om afholdenhed. Som Weininger udtrykker det: "Hermed er nu, udfra det hoieste Synspunkt af, Kvindespørgsmaalet som Menneske problem, Fordringen om begge Kjons Afholdenhed, fuldstendig begrundet." (s. 639)

Man kan undre sig over Weiningers store indflydelse i sin samtid. Men hans bog taler med autoritet til læseren om moderniteten som en ukontrollabel flodbølge, der vælter ind over manden og kulturen. Og fascinationen af Weininger døde ikke ud med modernitetens sejr. ${ }^{19}$ Selvom Weininger lod sig døbe og var antisemit, var han iøvrigt stadig med samtidens øjne en jøde. For Wittgenstein var han typen på den overlegne jødiske intelligens, som ikke passer ind $\mathrm{i}$ noget mønster. ${ }^{20}$

\section{Konrad Simonsen og Andre ORIENTALISTER}

Én af dem, som herhjemme blev dybt påvirket af Weininger var litteraten Konrad Simonsen (1876-1945).21 Simonsen havde oprindelig været brandesianer, men udgav i 1913 en hadefuld bog om Brandes: Georg Brandes (Jødisk Aand $i$ Danmark). ${ }^{22}$ Uanset at Simonsen sidenhen blev først kommunist, siden katolik og spiritist skal jeg beskxftige mig udelukkende med hans Brandes-bog, som et udtryk for, hvordan jødensom-begreb blev tænkt omkring første verdenskrig af en velreflekteret, højt uddannet akademiker og dr.phil. i litteraturvidenskab.

Simonsens raceteoretiske udgangspunkt er noget anderledes end Weiningers. Som han udtrykker det: "Her synes da Brandes at erkende, hvad han fornægter, naar det gælder ham selv: at det ikke er Sproget, ikke Religion eller Ateisme, men alene Blodet, der bestemmer et Væsens Særpræg [...]." (s. 16) Med 'blodet' tænker Simonsen på det biologisk irreduktible, det nedarvede slet og ret. At han placerer det i blodet, skal forstås metaforisk og ikke genetisk-videnskabeligt.

Bogen starter med en karakteristik af jøderne $\mathrm{i}$ almindelighed:

"Det er almindeligt anerkendt, at jødisk Aand har sin Styrke i højtudviklet praktisk Tænkning og merkantil Begavelse.

Ingen anden Race opviser saa mange og saa betydelige Finansmænd, Handelsspekulanter, Jurister, Læger og Journalister.

Jøderne $[\ldots]$ er $[\ldots]$ bleven de sejerrige i den materielle Konkurrence, og deres Magt er voksende, som Byerne tager til i Indbyggerantal, idet de fortrinsvis holder til i Storstæderne. [...]

Forbavsende er den Hastighed hvormed Jøderne opnaar Velstand, saasnart de har vundet Fodfæste i en fremmed Nation, mens vi i Reglen finder dem i Fattigdom, hvor de bor sammen i stort Antal. Det er ikke Arbejdslyst, men et udpræget Erhvervstalent, der faar dem til [...] bestandigt kun at opsøge Lande, der allerede er i andre Folkeslags Besiddelse, og hvor Kapital er forhaanden.” (s. 7f.)

Nu er det ikke jøderne som sådan Simonsen mener er problemet:

"Kun circa en halv Million Jøder har brudt med Ortodoxien, men det er denne halve Million, der udgør de rigeste, de "liberale Jøder"; det er den, der gærne fornægter sin Afstamning, sælger sine Ahner, hykler Kristendom og Omgivelsernes Patriotisme, blot der kan vindes frem derved. Det er denne halve Million, der kun viser Racens utiltalende Egenskaber; ene paa den turde vel passe Goethes Udtalelser om Jøderne i Almindelighed, at de mangler point d'honneur; thi det endnu langt overvejende Flertal Jøder - de troende og Zionisterne - udmærker sig ikke blot ved 
deres smukke, patriarkalske Familieliv, men ved deres Karakters Renhed og Stil.” (s. 8)

Det er altså de jøder, som har brudt med det traditionelle liv og som herigennem har fornægtet, at dette i følge sagens natur ikke kan lade sig gøre andet end som fornægtelse og derfor inautentisk og som maskerade, det er dem der er problemet.

Som Weininger var Simonsen meget optaget af tidens diskussion om geniet, overmennesket. Simonsen mener teoretisk, at det ville være antisemitisme, at frakende et så begavet folk som jøderne genialitet. Men han må i konstatere, at i praksis står det slet til. "Den væsentligste Aarsag til den ringe Genialitet hos Jøderne maa nærmest søges i deres fuldstændige Blottethed for Metafysik og deres ringe Fantasi. [...] Aldrig er der af jødisk Æt udgaaet et Geni i Prosalitteratur, i Maleri, Arkitektur eller Naturvidenskab." (s. 10f.) Det er et stort tema i samtiden, som Simonsen tager fat i: angsten for den jødiske begavelse. Hans pointe er imidlertid, at nok er jøderne begavede og snu, men de har ingen rigtig ånd og derfor kan de ikke være geniale. Deres funktion i Vesteuropa har derfor ikke været åndelig:

"Under Paaskuddet af at skulle evropæiseres og frigøres er dansk Kultur bleven underkastet jødiske Anskuelser, Moral og Vurdering. [...]

Anderledes bliver Forholdet, naar Jødernes Livssyn, der nærmest er Erhvervsaand, indpodes i et fremmed Folk. Dette er allerede Tilfældet i den mest af Jøder stiftede socialistiske og i den saakaldte liberale - i Virkeligheden jødiske og forjødede Presse, der nu behersker Amerikas og Evropas Storbyer. Allerede herved undermineres ikke blot Nationernes Ejendommelighed og deres religiøse og patriotiske Følelse, men deres Sans for alt højere Liv, idet liberal-jødisk Aand udelukkende er Spekulation i Menneskenes lavere Instinkter og Interesser.” (s. 12)

Jødisk ånd er således mangel på egentlig ånd.
Efter denne karakteristik af jødernes rolle går Simonsen over til en karakteristik af Georg Brandes. Den kan koncentreres i følgende udsagn: "Endskønt Georg Brandes ved enhver Lejlighed søger at hævde den jødiske Race som alle andre overlegen, protesterer han dog energisk mod selv at kaldes Jøde. [...] Denne utiltalende og umulige Bestræbelse for at skjule sine Spor, og [...] dette Forsøg paa at bringe sin Herkomst i Glemme [...] viser han altid selv, saasnart nogen fordrister sig til at bestemme hans Væesen som jødisk [...].” (s. 14)

Det centrale ved dette væsen, som han vil skjule, er at han ikke er én af 'os', dvs. en germaner: han er en orientaler. Det bliver den røde tråd gennem hele bogen: "Thi Brandes ved, han ikke blot ikke er dansk, ikke germansk, ikke af blandet Race heller og - mindst af alt en i Luften frit svævende Aand; han ved, at han er Orientaler, at han er Reformjøde." (s. 19) Og det viser sig at have mange konsekvenser: "Han var da ligestraks den, han vedblev at være $[\ldots]$ en Natur, snusfornuftig, længe ganske uerotisk, derpaa i sit Forhold til Kvinden fuldstændig orientalsk, om end hans Omtale af Kvinden klogeligt lyder respektfuld; [...]." (s. 21) Det er ikke mindst det lidenskabelige, som spontant træder frem af orientalerens mentalitet: "Hvor nordiske Skolebegavelser imidlertid har et sindigt Gemyt, der var Brandes sydlandsk lidenskabelig [...]." (s. 22) Men også det nomadiske viser sig at ligge i det orientalske blod: "Forskellen er kun, at Brandes i Stedet for at være revolterende Tænker, altid kun som Nomaden har elsket Udbyttersystemet, aldrig skabt noget." (s. 29) Ligesom ørkenen sætter sig sit umiskendelige præg: “Nej, der er Ørkenens tørre Øde og Rabbinerens golde Abstrakthed i hans Sprog." (s. 183)

Overalt dukker denne grundlæggende figur op som overgribende $\mathrm{i}$ forhold til alt hvad Brandes foretager sig. Således hedder det: "Orientaleren røber sig i Latterliggørelsen af og Angrebet paa det nordiske Hjem, Familielivet og Ægteskabet [...].” (s. 38) Li- 
gesom det viser sig som en modsætning mellem Brandes og Ibsen: "Modsat den romanske og orientalske Opfattelse af Kvinden som det dekorative Køn, som den æggende Elskerinde, der er en Fest for Sanserne, vil Ibsen grunde Forholdet mellem Mand og Kvinde paa en gensidig aandelig Vekselvirkning [...]." (s. 64) Hvordan vi end vender og drejer os, er det sådan: "I den Grad er Brandes racebunden, at skønt han forarges over, det kun overfladisk er lykkedes ham at paaklistre os sin israelitiske Livsanskuelse, kan han ikke selv paa et eneste Punkt sætte sig ind i ikkesemitisk Trnke- og Følemaade, men bedømmer ethvert Geni jødisk." (s. 96) Og som det hedder: "I Stedet skratter Georg Brandes' liberal-semitiske Røst." (s. 59) I stedet for at tale med ånd.

Simonsens udgangspunkt: at de jøder som var forblevet i traditionen var gode og smukke i deres patriarkalske ortodoksi, viser sig at blive undermineret af resten af analysen. I hvert fald kræver det, at man tilføjer: selvom traditionen er smuk, så er den uden ånd; den står på et lavere niveau end den germanske kultur; og den vil aldrig kunne blive til noget andet, det ligger i blodet.

Énsidigheden og hadefuldheden i Simonsens bog var også i samtiden påfaldende. Han havde brudt akademisk dekorum og bevæget sig ind i det, man også dengang opfattede som 'primitiv antisemitisme'. Bogen blev et akademisk selvmord for ham. Resten af sit liv flakkede han om som en nomade uden at blive anerkendt eller få et job. Når prisen blev så høj for ham, skyldes det dels énsidigheden, men også at han i bogen næsten udstiller sin homoseksualitet. Han bebrejder bl.a. Brandes, at han ikke forstår homoseksuelle genier som Shakespeare og Herman Bang. At (næsten) indrømme sin egen homoseksualitet var i 1913 betydeligt værre end at være jøde.

Selvom vi tager højde for ensidigheden hos Simonsen, så var det paradigme han tænkte i ikke et tilfældigt møde. Snarere må man sige, at racetankegang var det dominerende paradigme, som omgav ham på alle sider. Og pointen i Simonsens bog er også at Brandes selv tænkte i det paradigme, når han i Sainte-Beuves fodspor karakteriserede forfattere og fiktive personer. Racismen, altså kombinationen af biologisk determinisme med hierakisering af racerne i et system, holdt sig længst på højrefløjen i Danmark. Som eksempel - også i forhold til netop Brandes - kan vi bruge litteraten Harald Nielsen (1879-1957), som i Den store danske encyklopedi karakteriseres som "en skarpsindig kulturkonservativ". Han forholdt sig i en bog fra 1917 til Brandes' bog Verdenskrigen, som netop var udkommet i sin fjerde udgave. ${ }^{23}$ Heri skrev Nielsen om Brandes' kamp mod krigen til forskel fra dem som hyldede den: "Denne Forskel skyldes ikke politiske Overvejelser, ikke ophøjede moralske Hensyn, ikke vidtskuende Verdensplaner men er af den utvetydigste og snævreste nationale Oprindelse, d.v.s. ikke dansk-nationale, men jødisk-nationale." (s. 19)

Brandes' Verdenskrigen skulle altså ikke læses som en dansk bog, den havde en skjult undertekst: "Derfor er Frihandelen deres nationale Ideal - underforstaaet, fri og uhindret Adgang til at færdes hid og did, bosætte sig her og der, høste Berømmelse og Fordele overalt og uindskrænket af det taabelige Nationalhad at kunne række hinanden Haanden - $i$ national Samfolelse og Interessefallesskab." (s. 19) Nielsen kan derfor konkludere: "Med andre Ord: "Verdenskrigen" er ikke et dansk, men et jødisk-chauvinistisk Skrift [...]." (s. 30)

Da Cai M. Woel i 1928 udsendte sin essay-samling Det reaktionere Danmark. Literaturen og Tiden inkluderede han Harald Nielsen i bogen sammen med blandt andre: Henrik Pontoppidan, Knut Hamsun (selvom han ikke var dansker), Marie Bregendahl, Evald Tang Kristensen, Jacob Paludan, Jørgen Bukdahl og Henning Kehler. Reaktionær var et positivt ord i Woels ordbog, og han skrev bl.a. i forordet: "Bilerne suste og hyllede os i osende Stank, og i den forgik det gamle, det, der bar - og stadig bærer - Racens Præg, maaske fremelsket og 
tilkæmpet i bitre Kampe gennem Aarhundreder, det, der har Traditionens Klangfylde. En Verden gik under, og i Benzinstankens Kølvand fulgte meget andet "nyt", der tog Sindene." (s. 6) Den biologiske determinisme gik som et rød tråd gennem hele denne anti-modernisme.

Hos andre af periodens mindre skribenter møder vi den i samme usminkede stil som hos Simonsen. Hør engang forfatteren Harald Raage i hans bog Det forraadte Danmark (Kbh. 1920):

“Den store By krymper sig under Vampyrens sugende Nakkebid.

Under Vareaager og taabelige Indskrænkninger fornærmende i sin hensynsløse Hensigtsløshed for enhver Frimand.

Og imens breder Pesten sig fra en lille skidden og aandløs Races bugføre Smittebærere. Denne Pest, der saar Havesyge og Griskhed og bortæder unge Kvinders sunde Forstaaelse af eget Værd og gør dem til SalgsSkøger, der udriggede som Fantasifostre frembyder hele Varelageret Gade op og Gade ned, paa Byens mondæne Caféer, paa dens Sø-Promenade, i dens Forlystelses-Have. [...]

Og de er Smittebærere, ForraadnelsesSvampe, derfor deres Urenhed, deres Svinskhed. Det er den selvfølgelige Maske, hvorunder der arbejdes ihærdigt og essigt, ligesom pestbefængte Rotter gnaver og gnaver og kradser, til Grunden er undermineret og det tilsyneladende solide Hus skrider.

Skiddenhed er Lille-Asiatens bedste og mest beroligende Maske. Kræng Silkesokken af Semit-Bankieren, og Stanken vil sur og blomraadden stige..."24

Dette vrængende had til det moderne og dets personifikation i jøden som orientaler går gennem hele forsvaret for det traditionelle samfund. Selv i sammenhænge, hvor det ikke er negativt ladet, kan man finde det. Tænk f.eks. på Pontoppidans LykkePer. Her er det nye, kapitalismen og entrepenørånden, repræsenteret i den jødiske familie Salomon. Den er alt det som er frem-

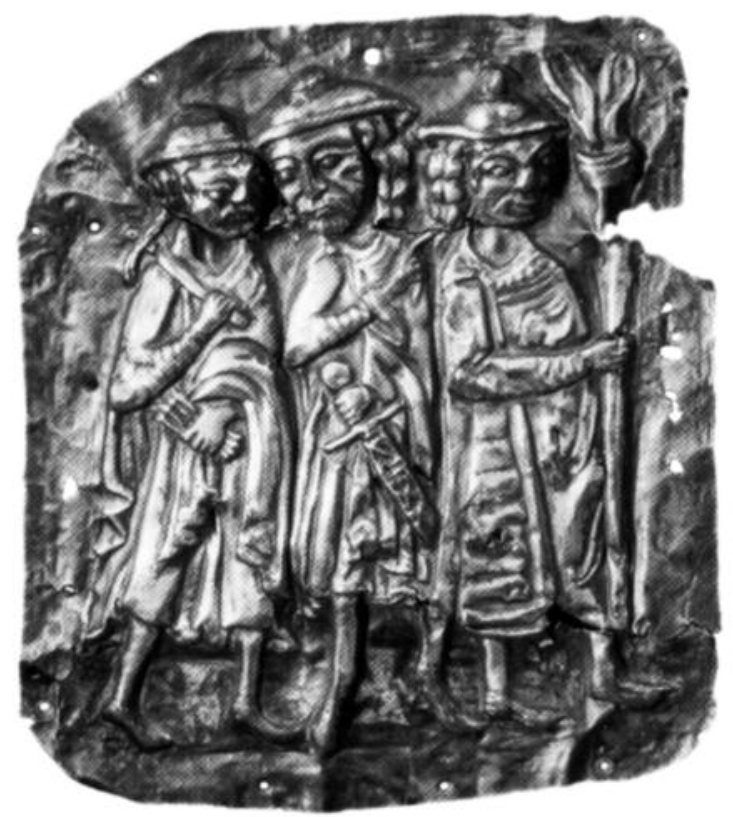

Joderne optrader ikke kun pa kalkmalerierne, men også på malerier som altertavler og som her pa et forgyldt kobberrelief fra ca. 1200, fundet pa heden ved Ars. Fremstillingen er ikke vrengende, som i mange andre tilfelde. De tre joder identificeres iser ved hjolp af deres hatte og deres lange hair.

med for Sideniuserne, de danske som Per selv. Per falder først for datteren Nanny med den tropiske seksualitet og en gangart som et rovdyr, men skifter siden til søsteren Jakobe med ørnenæsen. Portrættet af Jakobe ligger imidlertid meget fjernt fra antisemitisme, tværtimod er det ét af de smukkeste kvindeportrætter i dansk litteratur; hendes fremmedhed er blot irreduktibel.

Fra Harald Raages grovkornede racisme går der en lige linje til den kendte nazistiske film Die ewige Jude (1940), hvor jøder og rotter sidestilles. I den nazistiske forestillingsverden refererede 'orientalsk' uspecifikt til 'østpå', hvorfra både rotter og jøder kom ifølge filmen. Ikke overraskende finder vi også hos de danske nazister netop modsætningen mellem danske nordboer og asiatiske jøder, som f.eks. i sangen 'Til Bonden' af L.B. Therkildsen fra National-Socialisten 1934: 


"Som hos Frode
Fredegode
komme skal en Retfærdstid.
Vi skal vinde
Tusind Sinde
over Ondskab, Kiv og Strid,
over djævelske Magter
som med Asiaters Fagter
:/: lokker Nordens lyse Børn. :/:" 25

Det var imidlertid ikke kun antisemiterne, der så jøderne som orientalere. I juni 1938 mødtes de nordiske landes embedsmænd fra flygtningeadministrationerne med repræsentanter for flygtningekomiteerne for at undersøge, hvad der kunne gøres for ikke mindst de jødiske flygtninge. Det var svært at blive enige, men ét var man dog enige om, nemlig det ønskelige i at få sydamerikanske og asiatiske lande til at modtage flere jødiske flygtninge, da “jøderne er sydlændinge, hvorfor en emigration til f.eks. Sydamerika, hvis klima frembyder lighed med Palæstinas, også af denne grund er mere hensigtsmæssigt [end Europa]". Det var tyske og østrigske jøder der var tale om. ${ }^{26}$

\section{HVORDAN SER EN JØDE UD?}

I en meget interessant artikel har kunsthistorikeren Ulla Haastrup fornylig gjort opmærksom på det for mange sikkert overraskende, at der er masser af afbildninger af jøder i danske kalkmalerier fra middelalderen. ${ }^{27}$ Det burde måske ikke være så overraskende i betragtning af, at det overvældende flertal af motiverne er bibelske. Overraskende er det også, at der findes en billedkode for 'jøder'. De ser ud på en serlig måde, så man kan genkende dem som netop jøder. De har en krum næse, langt hår, skæg som ofte er delt i to, de afbildes oftest i profil og med åben mund, og så har de en hat på, som meget ofte er spids eller har en spids sat på. Ulla Haastrup gennemgår billedmaterialet, så man overbevises om den store betydning det har. Hun påviser også, at fremstillingen af jøder ændrer sig over tid. På den baggrund rejser hun det meget relevante spørgsmål: Selvom den skriftlige overlevering siger, at de første jøder kom til Danmark på invitation fra Chr. IV i 1622, kunne man så ikke på baggrund af billedhistorien anse det for sandsynligt, at der har været jøder i Danmark også i middelalderen?

Selvom den første skriftlige kilde, der bekræfter en jødes tilstedeværelse her, er fra 1592,28 og selvom der kunne findes andre, ${ }^{29}$ så ender vi ikke op med en situation, hvor jøderne viser sig at have været talrige i Danmark i middelalderen. Man kan næppe udelukke, at malerne fra nogle af værkstederne, som lavede kalkmalerierne, havde mødt rigtige, levende jøder ved markeder f.eks. i Nyborg (men det kunne også være i Altona eller Lübeck). Man kan forestille sig, at nogle af malerne faktisk har set en jøde. Men det er næppe det centrale, selvom det muligvis kan forklare udviklingen i visse træk (hattene f.eks.). Nej, den centrale pointe er, at beskuerne af kalkmalerierne har forstået, at her var der tale om en jøde. Aflæsningen af billedkoden 'jøde' forudsætter imidlertid slet ikke, at man nogensinde har set en jøde - og den altdominerende del af danskerne i middelalderen havde med garanti aldrig set en rigtig jøde.

Det er klart, at man for nogle af elementerne i billedkoden kan pege på referenter $\mathrm{i}$ 'virkeligheden': jødiske mænd (og det er næsten kun mænd, vi ser afbildet) har skæg, nogle af dem har givet haft ørekrøller (pejes) og mange af dem har givet gået med hat. Men hvad med næsen? Har jøder da ikke store, krumme næser?

J.V. Spärck refererer en undersøgelse fra dette århundredes begyndelse af 4.000 indvandrede jøder i New York. I denne undersøgelse havde $58 \%$ af mændene en lige næse, $14 \%$ havde en buet, $22 \%$ en opadstræbende, mens $6 \%$ havde en flad, bred næse. For kvinder var tallene henholdsvis 59, 13, 14, 14.30 Iøvrigt henviser Spärck også til undersøgelser, som viser, at mellem $15 \%$ og 30\% af jøder er blonde (afhængig af gruppe) og op imod 50\% har lyse øjne. 
Den store buede 'jødenæse' er altså ikke statistisk set en reference til virkeligheden. Ejheller (når vi taler om europæiske jøder) det mørke hår og de brune øjne. I Ruth Mellinkoffs overdådige værk Outcasts: Signs of Otherness in Northern European Art of the Late Middle Ages, ${ }^{31}$ hvor hun beskæftiger sig med, hvordan 'de andre', de udstødte, jøderne, narrene, de anstødelige osv. repræsenteres i kunsten, skriver hun, at den store næse er en billedkode for degradering. Den skal, ligesom den åbne mund (og profilportrættet tilføjer Ulla Haastrup) aflæses som en bevidst degradering af den afbildede person. Billedkoden for 'jøde' er simpelthen en karikatur (bd. 2, 127ff.). Bernhard Blumenkranz gør opmærksom på, ${ }^{32}$ at denne karikatur allerede kendes fra Spanien i 1200-tallet. Til gengxld er denne kode blevet så fast inventar i den billedmæssige fremstilling af jøderne, at det måske er den mest centrale. Når koden eller tegnet er blevet til i middelhavslandene kunne man yderligere pege på, at 'jødenæsen' formentlig netop dér findes blandt ikkejøder i en udstrækning, som gør det helt illusorisk at tro, at den skulle referere til virkeligheden. Med tiden er karikaturens tegn blevet ikke blot ikonen for 'jøde', men i manges opfattelse tillige et tegn med en referent i virkelighedens verden.

Virkelige jøder er ikke nødvendige for at have en billedkode, som betyder 'jøde'. Lige så lidt som Djævlen er nødvendig for at have en billedkode, som betyder 'djævel' eller havfruen, eller heksen. I Nordeuropa var der sparsomt med jøder lang tid efter kristendommens sejr, men afbildet blev jøder alligevel. I England var jøderne forment adgang i 400 år, men det stoppede ikke fremstillingen af jøder dér.

Man kan generalisere dette synspunkt: modvilje mod jøder eller jødehad kræver ikke at der findes jøder. Jødehadet er knyttet til kristendommen og til fortolkningen af jødernes rolle i Det nye testamente. Denne fortolkning har været omskiftelig ikke mindst fordi, kristendommen betragtede sig som den legitime fortsætter af den religion Gud havde indstiftet for jøderne, blot med den tilføjelse at Messias havde veret der. Men fortolket blev der uanset om fortolkerne i deres liv kendte til reelt eksisterende jøder. Hvis nu det jødiske folk var døet ud som folk i de første århundreder efter romernes ødelæggelse af Jerusalem, havde jøder alligevel eksisteret i den kristne fortolkning og i den muslimske. Og den muslimske fortolkning (og modvilje) bygger når det kommer til stykket på den kristne tradition. Man kunne sagtens have haft en lang billedtradition for afbildning af en sådan ikke-eksisterende entitet. Som de mytiske figurer. Og lidt ligesom en viking $\mathrm{i}$ dag fremstilles med hornet hjelm og identificeres med denne billedkode, men aldrig bar en sådan hjelm i virkeligheden.

Jødedommen døde imidlertid ikke ud. I lange tider var kristendommen og jødedommen konkurrenter. Jødedommen kunne missionere og tiltrække proselytter måske hele folkeslag som khazarerne. ${ }^{33}$ Jøderne var nemlig både et folk og en religion, man kunne konvertere til. De faktisk eksisterende jøder (af afstamning eller konversion) stødte sammen med de overleverede antijødiske holdninger. Dette sammenstød var en grundlæggende og tillige meddefinerende parameter i jødernes historie. Perioder med lavt blus på modsætningerne afløstes i en for jøderne uforudsigelig rækkefølge af modsætninger, massedrab og fordrivelser. Man kan efter min mening ikke forklare disse ændringer ud fra jødernes historie eller deres tilstedeværelse. Tværtimod tvinges man altid til at finde årsagerne i ikke-jødernes historie.

Jødehadet og senere antisemitismen eksisterer som et sammenhængende sæt af forestillinger fra tidlig middelalder (eller før) til i dag. Det er et sæt af formler (billedkoder, tekstkoder, forestillinger, drømme og andre ubevidste manifestationer), som kan knytte sig til stort set et hvilket som helst historisk indhold. Kontinuiteten i jødehadet er derfor tilsyneladende, fordi enhver opblussen 
af had finder sted under ændrede vilkår, men i former som ligner tidligere udbrud. Jødehadet og senere antisemitismen er, som andre af de former der findes i den folkelige overlevering, åben for forbløffende xndringer.

At det forholder sig således har medført en række konsekvenser. For det første at jøderne ikke selv har kunnet handle i forhold til antisemitismen. For det andet at jødernes historie blev formet afgørende af kræfter uden for de jødiske samfund. For det tredje at jøderne måtte fungere som projektionsobjekt for meget forskelligartede angstforestillinger - fra religiøse og kulturelle til økonomiske og sociale. For det fjerde at jøderne selv tenderede til, at se deres historie på den måde, at overalt hvor de kom, fremprovokerede de jødehad.

Jeg siger ikke hermed, at jøderne ingen rolle har spillet i deres egen historie. Slet ikke. Kun at den, for så vidt som jødehad og antisemitisme spiller en rolle, er overdetermineret udefra. Som jøden er 'den anden' for ikke-jøden, er jødehadet 'den anden' for jøden.

Antisemitismen, jødehadets moderne form, begynder med raceforestillingerne og med jødens orientalisering. Vi har set, at antisemitismen bl.a. opsamler angsten for moderniteten. Men der er flere andre former for angst, den kan rumme. Én af de største antisemitiske bestsellere er Zions vises protokoller, ${ }^{34}$ en forfalskning udført af tsarens hemmelige politi, som fremstiller en jødisk konspiration med henblik på at erobre verdensmagten. Protokollerne kan læses som en angst for de processer i moderniteten som er uden subjekt, men påvirker alle subjekter; en angst som Protokollerne giver et subjekt; subjektet finder den takket være antisemitismen i jøderne.

Når jøderne orientaliseres hænger det næppe udelukkende sammen med at kristendommens tekster udspilledes i Mellemøsten. Andre har f.eks. tolket jøderne som sorte. ${ }^{35}$ Samtidig med nationalismen foregik en europæisk ekspansion i Asien og
Afrika. Denne ekspansion åbnede europæernes øjne for de 'mange andre'. Selvom europxerne forholdt sig til asiater, negre og andre tredie verdensfolk som subjekter til objekter, ${ }^{36}$ producerede disse objekter megen angst hos undertvingerne. Orientaliseringen af jøderne i Europa kan også læses på den måde, at jøderne var et koloniseret folk i kolonimagternes egne hjemlande.

\section{REORIENTERING OG ORIENTALISME.}

Samtidig med nationalismen i Europa opstod 'det jødiske spørgsmål'. I den sammenhæng, jeg her har ridset op, kan de jødiske svar på det jødiske spørgsmål forstås som en reorientering og som forsøg på at gøre jøderne til subjekter $\mathrm{i}$ deres egen historie. Assimilation var én strategi. Den strategi blev imidlertid kraftigt imødegået fra to sider: fra den jødiske socialisme og fra zionismen. Den jødiske socialisme (eller bundismen) ville ikke ophæve jødedommen gennem assimilation, men derimod fastholde jøderne som et folk i moderne forstand. Når bundisterne talte om jøderne, talte de om de jiddish-talende, ashekenaziske jøder i Østeuropa. Som et folk havde jøderne krav på autonomi indefor rammerne af de nationer, hvori de levede. Autonomien skulle gøre jøderne til et historisk subjekt dér, hvor de faktisk boede. Bundisterne så dermed antisemitismen som en historisk form, som kunne bekæmpes og som kunne forsvinde.

Zionisterne mente ikke antisemitismen kunne forsvinde, den var bundet til jøderne, som skyggen til en person. Derfor måtte jøderne skaffe sig et land, hvor de kunne være og blive en 'normal' nation. Man kunne, mente de, kun afskaffe antisemitismen ved at flytte dens årsag, jøderne, til et tomt landområde.

Det med 'tomt' var der nu ingen, der sagde; men både Theodor Herzl og arbejderzionisterne handlede som om Palæstina var tomt. For det var det gamle, mytiske land zionisterne havde i tankerne. Og som 
vi alle ved blev bundismen umuliggjort af Hitlers massemord på flertallet af de europæiske jøder, og det skabte zionismens vækstmuligheder og staten Israel. Lige siden har der været problemet med at landet ikke var tomt. Det vil jeg imidlertid lade ligge her, og i stedet intessere mig for et andet aspekt ved zionismens realisering.

Der fandtes faktisk orientalske jøder. Til forskel fra de jiddish-talende ashkenazer og de judezmo-talende sefarder bestod denne brokkasse af en lang række jødiske grupper, som havde det tilfælles, at de ikke boede $i$ Europa, men $i$ Asien og Nordafrika. Det drejede sig om judeo-arabisk-talende jøder i Mellemøsten og Nordafrika, farsi-talende jøder i Iran, judeo-tat-talende bjergjøder i Kaukasus, marahti-talende bene-israel-jøder i Indien og amharisk-talende beta-israel-jøder i Etiopien. Så sent som omkring 1900 fandtes der mandarin-talende, kinesiske jøder i Kaifeng. De orientalske jøder så meget forskellige ud. Bene-israel-jøderne fra Indien er meget mørke, beta-israel-jøderne er sorte som negre, mens de kinesiske jøder lignede kinesere.

Zionismen var et europæisk projekt. Men det var formuleret universelt for alle jøder. Da den europæiske indvandring til Israel stagnerede efter 1950, og det blev klart at de amerikanske jøder ikke ville udvandre, begyndte den israelske stat på forskellig vis at stimulere indvandringen af orientalske jøder. Én af de første grupper som kom var de mørke bene-israel-jøder fra Indien. De så så fremmedartede ud, at rabbinaterne $\mathrm{i}$ Israel bestemte, at de skulle kunne bevise, at de var jøder i mange generationer for at blive anerkendt som jøder. Da dét er en forudsætning for at blive israelsk statsborger var det ret afgørende. Men hvem kan tusindvis af kilometer fra Indien bevise, at man har haft en jødisk mor i fire generationer. ${ }^{37} \mathrm{Og}$ måske kunne det slet ikke dokumenteres. Faktisk kom det til voldsomme konflikter omkring dette særkrav til de orientalske jøder, så Levi Eshkol måtte gribe ind og presse rabbinaterne til en løsning, som gjaldt alle og ikke kun de indiske jøder. ${ }^{38}$ Det var blot begyndelsen på en lang historie om hvordan det europæiske projekt blev forsøgt orientaliseret. Kulminationen kom, da det lille højreorien-

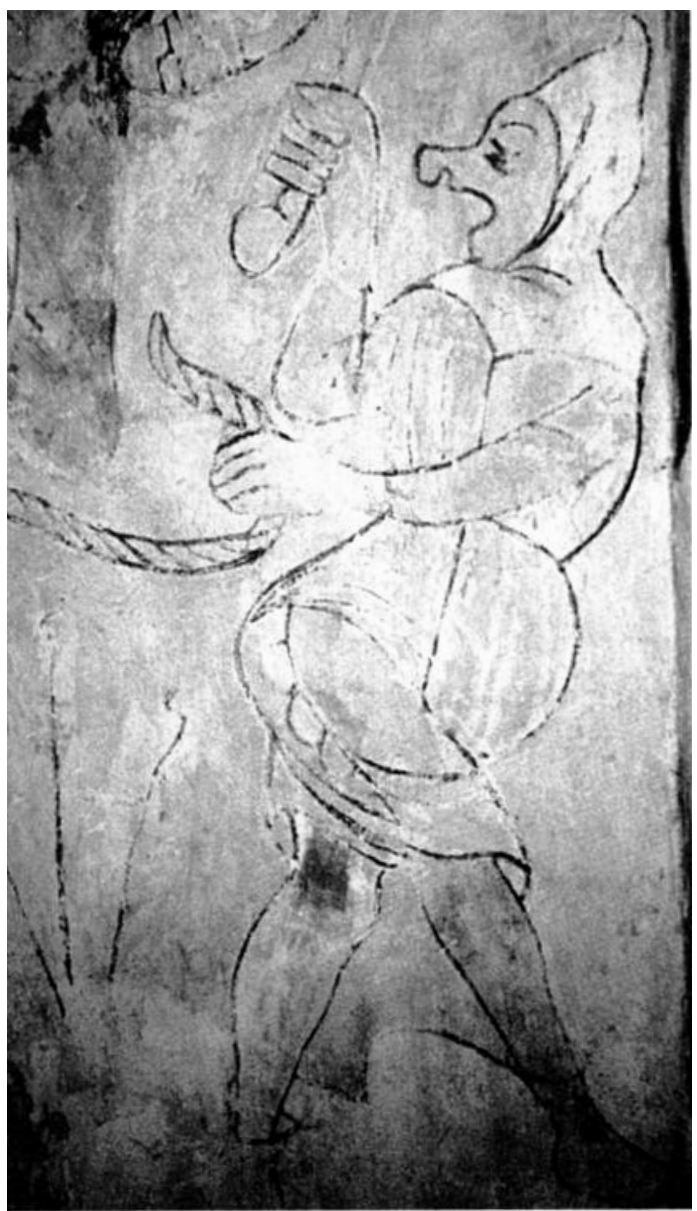

Scene fra korsboringen i Reerslev Kirke, ca. 1460. Denne jode er fremstillet i profil med äben mund og stor nese og med hat på. Han har tofarvede stromper. Det kulorte var også et nedvardigende trek. Endelig viser han sin bare rov for at ydmyge Jesus.

terede parti Likud omkring Menachem Begin vandt magten fra Arbejderpartiet på orientalske stemmer. De orientalske jøder ønskede ikke at blive europæere og ikke at lade sig styre af europæiske jøder. For dem var Israel et samfund i Orienten. 
Når Salman Rushdie taler om desorientering, taler han om at tabe Østen. Dét er hvad de orientalske jøder har gjort. Israel er ikke et orientalsk samfund, men et hybrideuropæisk samfund. De gamle zionister mente, at man kunne begynde på en frisk, skrive på en ren tavle, starte en ny ren kultur. I stedet blev Israel et multikulturelt samfund, som i nogen henseender ligner andre af de nyere indvandrersamfund (USA, Australien, Syd-Afrika, New Zealand). Kludetæppe i stedet for renhed. Desorienteringen blev den form, under hvilken Orienten endelig mødte en betydelig del af verdens jøder.

\section{Noter}

1. Salman Rushdie: The Ground Beneath her Feet. A Novel, London 1999; da. overs. samme år. 2. Jacob Baden: Almeenyttig Alphabetisk Ordbog over de $i$ danske Skrifter og $i$ Omgangssproget meest brugelige, af fremmede Sprog laante, Ord, Talemaader og Konstudtryk, Kjøbenhavn 1824.

3. Ludvig Meyer: Kortfattet Lexikon over fremmede, $i$ det danske Skrift- og Omgangs-Sprog forekommende Ord, Konstudtryk og Talemaader tilligemed de $i$ danske Skrifter mest brugelige, fremmede Ordforkortelser, Kbh., 1837

4. Peter Skautrup: Det danske sprogs historie, III, København 1953, s. 339.

5. Ifølge Skautrup (bd. II, s. 22) er Mandevilles rejse forfattet at englænderen Johannes de Mandeville i 1355-56 vistnok på fransk. Rejsen siges at have fundet sted fra 1322 og 33 år frem. Citaterne er fra uddraget af Mandeville i Nelly Uldaler og Gerd Wellejus: Gammeldansk lasebog, Kbh. 1968, s. 249ff. Hele teksten findes i M. Lorenzen (udg.): Mandevilles Rejse i gammeldansk Oversattelse tillige med En Vejleder for Pilgrimme efter Händskrifter udgiven, Kbh. 1882.

6. Oldislandsk 'ju i'; det almindelige ord var imidlertid 'gy ^ingr', afledt af ordet 'gu ', gud. Jøderne var altså 'gudlinger'.

7. F.eks. for de iberiske, sefardiske jøder. Se Hanne Trautner-Kromann og Salomon Schulman (red.): Dopet eller Döden. Judiskt liv $i$ medeltida Spanien, Stockholm/Stehag 1996.

8. Lewis Henry Morgan: Ancient Society; or, Researches in the Lines of Human Progress from Savagery, through Barbarism, to Civilization, London og New York 1877.
9. Benedict Anderson: Imagined Communities. Reflections on the Origin and Spread of Nationalism, London 1983.

10. Se min artikel: Løver og abekatte. Eller hvad er danskhed?, Henrik Ljungberg og Erik Svendsen (red.): Ud af det moderne. Den kritiske tanke anno 2000, Kbh. 2000, s. 43-58.

11. Ægteskabet med sprogvidenskaben gav det utilsigtede problem, at sigøjnerne måtte regnes til den ariske race, da de talte et indo-europæisk sprog og formentlig nedstammede fra de sanskrittalende ur-ariere. Derfor var nazisterne længe splittet i holdningen til sigøjnerne. Nogen mente, at man burde holde dem i en slags reservat, og at det kun var bastarderne, Mischlingene, som var et problem. Se Michael Zimmermanns bog Verfolgt, vertrieben, vernichtet. Die nationalsozialistische Vernichtungspolitik gegen Sinti und Roma, Essen 1989. 12. Se f.eks. Joseph Jacobs: On the Racial Characteristics of Modern Jews, Journal of the Anthropological Institute of Great Britain and Ireland, vol. 15/1886, s. 23-62.

13. J.V. Spärck: Den såkaldte "jødiske race”, Kaj Birket-Smith, J. Spärck, Louis Hjelmslev, J. Balslev Jørgensen og Mogens Westergaard: Arv race og kultur, Kbh. 1954, s. 38

14. Jean-Paul Sartre: Réflexions sur la question juive, Paris 1954 (men delvis skrevet i 1944), genoptr. 1980 , s. 23.

15. I pjecen Der Sieg des Judenthums über das Germanenthum. Vom nicht confessionellen Standpunkt aus betrachtet, Berlin 1879; i 1880 udsendte Marr tre numre af Antisemitische Hefte i Chemnitz. Ordet bredte sig hurtigt. Ordbog over det danske Sprog (Suppl.bd. 1) citerer Social-Demokraten fra 8.1.1881: "Den antisemitiske Bevægelse har... grebet stærkt om sig blandt Studenterne ved Tysklands Universiteter". Oxford English Dictionary angiver ligeledes 1881 som det første fund i engelsk. 16. På engelsk staves ordet oven i købet anti-Semitism, men ordet Semitism eksisterer ikke.

17. Der citeres fra: Dr. Otto Weininger: Kjøn og Charakter. En principiel Undersøgelse. Oversat af Karl Gjellerup, Kjøbenhavn 1905, 644s. Gjellerup er ansvarlig for den (også i 1905) gammeldags ortografi, den noget germaniserende syntaks, men især for en guerillakrig mod Weininger i fodnoterne.

18. Freud: Analyse der Phobie eines fünfjährigen Knaben ["Der kleine Hans"], Freud: Studienausgabe, Bd. VIII, Frankfurt/M 1969, s. 36, note 2. 19. Om Weininger, se: Jacques Le Rider: Le cas Otto Weininger: Racines de l'antifeminisme et de l'antisémitisme, Paris 1982; Jacques Le Rider og Norbert Leser (udg.): Otto Weininger: Werk und 
Wirkung, Wien 1984; Nancy A. Harrowitz og Barbara Hyams: Jews and Gender: Responses to Otto Weininger, Philadelphia 1995; Chandak Sengoopta: The unknown Weininger: Science, philosophy and Cultural Politics in Fin-de-siècle Vienna, Central European History 1996/vol. 29/4/s. 453494; Ritchie Robertson: Historicizing Weininger: The Nineteenth-Century German Image of the Feminized Jew, Bryan Cheyette og Laura Marcus (udg.): Modernity, Culture and 'the Jew', Cambridge 1998, s. 23-39.

20. Se Sander L. Gilmans interessante artikel: Smart Jews in Fin-de-siècle Vienna: 'Hybrids' and the Anxiety about Jewish Superior Intelligence - Hofmannsthal and Wittgenstein, Modernism/Modernity 1996/3.2/s. 45-58.

21 . For en introduktion, se min artikel: I søgen efter kærlighed og sandhed. Konrad Simonsen 1876-1945, Morten Thing: Portratter af $10 \mathrm{kom}$ munister, Kbh. 1996, s. 98-125.

22. Konrad Simonsen: Georg Brandes (Jødisk Aand $i$ Danmark), Nationale Forfatteres Forlag, Kbh.

$1913,187 \mathrm{~s}$.

23. Harald Nielsen: Jøden Filisteren og Holsteneren, Kbh. 1917.

24. Cit. efter Karsten Koch, Elo Nielsen og Søren Schou: Hagekorset $i$ Norden. Et udvalg af nordisk nazistisk litteratur, Kbh.1983, s. 9.

25. Cit. efter Ole Ravn: Dansk nationalsocialistisk litteratur 1930-45, Kbh. 1979, s. 89f.

26. Lone Rünitz: Danmark og de jødiske flygtninge 1933-1940, Kbh. 2000, s. 110.

27. Ulla Haastrup: Jødefremstillinger i dansk middelalderkunst, Mirjam Gelfer Jørgensen (red.):

Dansk jødisk kunst. Jøder $i$ dansk kunst, Kbh. 1999, s. 111-167.

28. Karsten Christensen: Jochim Jøde i Helsingør i 1592, Tidsskrift for Dansk Jødisk Historie

24/1987/s. 11-16.

29. Ulla Haastrup nævner, at en kilde fra 1537 omtaler et "Jødestrædhe" i Nyborg, og at ordene 'jøde' og 'jyde' i nogle gammeldanske tekster skrives med det samme ord: 'judhe'.

30. J.V. Spärck: Den såkaldte "jødiske race”, Kaj Birket-Smith, J. Spärck, Louis Hjelmslev, J. Balslev Jørgensen og Mogens Westergaard: Arve race og kultur, Kbh. 1954, s. 26; undersøgelsen er M. Fishberg: The Jews. A Study of Race and Environment, New York 1911.

31. Ruth Mellinkoff: Outcasts: Signs of Otherness in Northern European Art of the Late Middle Ages, 12, Berkeley 1993.

32. Bernhard Blumenkranz: Juden und Judentum in der mittelalterlichen Kunst, Franz DelitzschVorlesungen 1963, Stuttgart 1965, s. 24f.

33. Det khazariske rige lå mellem Sortehavet og Det kaspiske Hav. I 861 konverterede kong Bulan til jødedommen, og ikke mindst kong Obadias (870erne) byggede synagoger over hele landet og gjorde meget for at udbrede jødedommen. I 960erne begyndte den russiske erobring af khazarriget og omkring 980 gik kongen over til kristendommen. Omkring 1016 var det slut for khazarriget. Se bl.a. Kevin Alan Brook: The Jews of Khazaria, Northvale og Jerusalem 1999.

34. Se Norman Cohns nu klassiske bog Warrant for Genocide. The Myth of the Jewish World Conspiracy and the Protocols of the Elders of Zion, London 1967; genoptryk London 1996.

35. I 1910 udkom Arthur T. Abernethys bog The Jew a Negro, Being A Study of the Jewish Ancestry from an Impartial Standpoint, Moravian Falls, North Carolina; se også Leonard Rogoffs interessante artikel: Is the Jew White?: The Racial Place of the Southern Jew, American Jewish History 1997/85.3/s. 195-230.

36. I Frankrig og England er det almindeligt at afbilde relationen mellem koloni og kolonimagt som en kønsrelation med kolonierne som kvinder. 37. At være født jødisk er ifølge halakhisk (jødisk religiøs) lov det samme som at ens mor er jøde. 38. Der er tre grupper indiske jøder: Cochin-jøderne i sydvest, Bene Israel jøderne i vest og Bagdad-jøderne i Bombay. De to første grupper er 'sorte' jøder, den sidste er 'hvide' jøder. De to første talte marathi, den sidste arabisk og siden engelsk. Om deres historie og deres emigration til Israel se Joan G. Roland: The Jewish Communities of India. Identity in a Colonial Era, New Brunswick 1998.

\section{SUMMARY:}

This article historizes the terms the "Orient" and "orientals" by using anti-feminist and anti-semitic writing from the 19th century. The Jews were in science and literature portrayed as the "Others" within Europe, and the author discusses the cultural changes, which are viewed as a critique of nationalism but also as a critique of modernity.

Morten Thing, Lektor, dr.phil.

Roskilde Universitetsbibliotek 